DOI: 10.35784/IAPGOS.34

\title{
DYE PHOTOSENSITIZERS AND THEIR INFLUENCE ON DSSC EFFICIENCY: A REVIEW
}

\section{Ewelina Krawczak}

Lublin University of Technology, Institute of Renewable Energy Engineering, Lublin, Poland

Abstract. Since early 1990s dye-sensitized solar cells (DSSC) has been developed by many research groups all over the World. This paper presents a review of researches focusing on photosensitizer influence on DSSC efficiency. Variety of dye substance has been analyzed. The highest efficiency around $11.2 \%$ has been noted for ruthenium-based DSSC devices. Natural dyes allowed to reach $4.6 \%$. The most metal-free organic dyes resulted in efficiency ranged from $5 \%$ to $9 \%$, however, some of them (e.g. Y123) allowed to obtain devices with efficiencies equal to $10.3 \%$. Co-sensitization is the new approach which results in efficiencies up to $14.3 \%$.

Keywords: photovoltaic cells, renewable energy sources, energy conversion, DSSC

\section{SUBSTANCJE SENSYBILIZUJĄCE I ICH WPLYW NA SPRAWNOŚĆ BARWNIKOWYCH OGNIW SLONECZNYCH (DSSC): PRZEGLĄD}

Streszczenie. Od początku lat 90 XX wieku ogniwa barwnikowe przyciagaja uwage naukowców na calym świecie. Praca ta poświęcona jest przeglądowi badań dotyczacych wplywowi substancji sensybilizujacych na sprawność barwnikowych ogniw słonecznych (DSSC). Największa sprawność uzyskuja ogniwa sensybilizowane barwnikami na bazie rutenu, podczas gdy barwniki naturalne pozwalaja na pracę z wydajnościa 4,6\%. Sprawność konwersji energii ogniw uczulanych barwnikami organicznymi wynosi 5-9\%, jednakże niektóre z nich, np. Y123 pozwalaja na uzyskanie wydajności rzędu 10,3\%. Zastosowanie kilku barwników do sensybilizacji jest nowym podejściem, które przekłada się na wartości sprawności nawet do 14,3\%.

Słowa kluczowe: ogniwa fotowoltaiczne, odnawialne źródła energii, konwersja energii, barwnikowe ogniwa słoneczne (DSSC)

\section{Introduction}

Nowadays renewable energy sources are becoming more important due to the intense development of society combined with the depletion of fossil fuels. It should be noticed that energy demand is still increasing. One of the reasons is a tremendously growing population and significant improvement of its living standard. Another reason is the industry enhancement. Electricity is a core resource for the development of human civilizations. It is anticipated that power demand increases by $90 \%$ from today to 2040 , because of the use of electric mobility, heating, and common electricity access $[46,55]$. However, the current scheme of supply and use of energy is unsustainable and it should be stabilized in the short-time perspective. What is more, global warming and the climate change force the present generation to search environmentally friendly energy technologies which will contribute to sustainable development for the subsequent generations. Electricity can be received from various resources such as coal, natural gas or biomass. It should be taken into account that fossil fuels combustion has a tremendous impact on the environment. Environment preservation during the energy production process is crucial. Therefore, the energy production method should be reoriented towards renewable resources. Greenhouse gases emission, such as $\mathrm{CO}_{2}, \mathrm{SO}_{\mathrm{X}}, \mathrm{NO}_{\mathrm{X}}$, to the atmosphere is limited by Directive 2009/28/EC of the European Parliament and of the Council of 23 April 2009 on the promotion of the use of energy from renewable sources which assumes the emission reduction. What is more, European Council has presented a variety of legislative proposals related to the reform of the EU energy market called "Clean Energy for All Europeans". On the basis of these documents, Poland should achieve $32 \%$ of renewable energy sources in final energy consumption by the end of 2030 [54]. The renewable energy sources are characterized by high temporal and spatial variability thus they need to be carefully balanced and used in the national energy plan in order to maintain a well-balanced supply. Solar photovoltaic technology has tremendous high potential energy contribution which can fulfil the energy demands of the entire world. Therefore, and having regard to this fact, harvesting and supplying photovoltaic (PV) technologies should be readily available [7]. Photovoltaic use the direct conversion technology of sunlight into high-quality electricity energy. Three main categories of photovoltaic solar cells, called generation, can be distinguished. Currently, the market is covered by the first two. The most-known, the first generation is based on crystalline silicon material. The silicon wafers production and environmental costs are relatively high, but this technology is the most effective one. The research group of Yoshikawa [50] achieved efficiency equals 26.7\%. The second generation of solar cells, which is called thin-film technology, is mainly based on cadmium sulfide $(\mathrm{CdS})$, cadmium telluride (CdTe), amorphous silicon (a-Si) and copper-indiumdiselenide/copper-indium-gallium-diselenide (CIS/CIGS). P. Jackson et al. [18] produced CIGS laboratory solar cell with the highest efficiency of $22.4 \%$. It has created the opportunity to replaced high-cost conventional silicon solar cells with CIGS ones. However, the type of solar cells which focuses the attention of research groups all over the world are dye-sensitized solar cells (DSSC). They belong to the third generation of photovoltaic cells which is classified as a cost-effective photovoltaic device mainly due to inexpensive materials and simple fabrication process. After the breakthrough, in 1991, made by the group of Gratzel [32], DSSC are considered as one of the most potential renewable power sources. In contrast to conventional solar cells based on the p-n junction made of semiconductor, DSSC consist of four main components:

1) photoanode, called working electrode, with a mesoporous semiconductor layer (mostly made up of titanium dioxide $\left(\mathrm{TiO}_{2}\right)$ );

2) counter electrode covered by a catalyst which is typically platinum;

3) electrolyte containing the redox couple; its main role is to collect electrons at the counter electrode and dye sensitizerregenerating;

4) dye sensitizer absorbed on the $\mathrm{TiO}_{2}$ molecules.

The scheme of dye-sensitized solar cells is presented in Fig. 1.

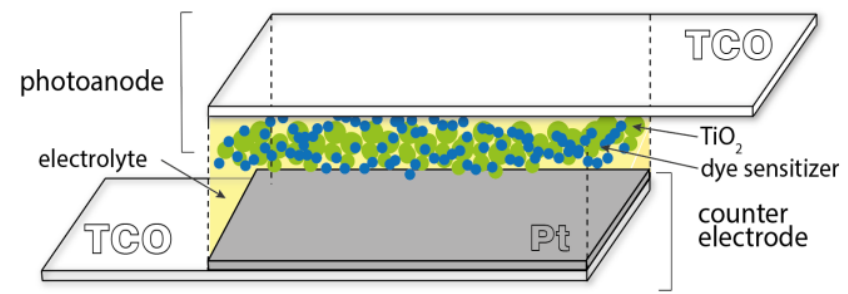

Fig. 1. Scheme of dye-sensitized solar cells 
Dye-sensitizer solar cells are photoelectrochemical devices which use an electrolyte as the charge transport medium. Both electrodes are based on transparent conductive oxide (TCO) substrates. They are covered by several microns thick of mesoporous and nanostructured indium tin oxide (ITO) [38] or fluorine-doped tin oxide (FTO) [26]. In the process of manufacturing the DSSC, FTO material is more common, because is high temperature resistant which is important since the working electrode covered with TCO and semiconductor needs annealing treatment. At relatively high temperature degradation of electrical properties of ITO layers can appear, whilst layer based on fluorine-doped tin oxide is much more stable. ITO is characterized by the highest available optical transmittance of $\sim 90 \%$ in visible spectrum light with the lowest electrical resistivity of $\sim 10^{-4} \Omega \cdot \mathrm{cm}$ [28]. Among all the components, the dye plays a crucial role in the conversion of sunlight into electricity $[1,19]$. Its role is to extend the absorption of solar light by mesoporous $\mathrm{TiO}_{2}$ layer from visible to the near-infrared range (up to $920 \mathrm{~nm}$ ) in the solar spectrum and thus increasing the efficiency of solar conversion [10]. It should be pointed out that DSSC use electron transfer reactions in a molecular scale. The initial efficiency that achieved by Gratzel equals 7\% in 1991 [32], then it raised up to the value of $10 \%$ in 1993. Nowadays, the most efficient DSSC device works with an efficiency of $13 \%$ [30]. The attention on many research groups is focused on clarification of DSSC working principles, improvement of conversion efficiency, and commercialization.

Dye-sensitized solar cells have many components that have to be optimized not only as an individual but also as a part of the highly-advanced assembly. The efficiency of working cells absolutely depends on the type of substance used as dye sensitizer. This review article aims to represent recent studies of dyes that have provided important pathways towards better device performance.

\subsection{Dye sensitizer}

The efficiency of dye-sensitized solar cells is strongly determined by the molecular structure of the photosensitizer [43]. Roslan et al. [34] divided the photosensitizers into three groups: metal-complex, organic and natural photosensitizer. However, some research groups, such as $[3,17,24]$ distinguish into natural and synthetic substances (metal complex dyes and metal-free organic dyes). The group of synthetic sensitizers is represented by e.g. polyphyridal complexes of ruthenium and osmium, metal porphyrin, whereas organic one includes natural and synthetic substances. However, the principal criteria that are taking into account are an environmental influence, manufacturing, and origin of the dyes, ability of absorbance the wide spectra of the light and durability. The whole surface of the nanoparticles titanium dioxide should be covered with a single layer of molecules' dye which causes the effective electron injective into the semiconductor material directly. It would be low effective or even impossible if it was realized through the few layers of sensitizer.

What is more, an ideal dye sensitizer should fulfil important requirements, which are as follows [12, 49, 52]:

1) wide absorption spectrum; maximum photons harvesting from visible to the near-infrared region;

2) production of photo-excited electrons;

3) the ability of effective charge infusion into the conduction band of the mesoporous semiconductor layer;

4) appropriate levels of LUMO and HOMO providing effective electrons injection;

5) ability to dye regeneration; the oxidation potential of dye should be higher than the oxidation potential of redox couple contained in an electrolyte;

6) presence of chemical groups that are capable of permanent chemisorption of photosensitizer onto the $\mathrm{TiO}_{2}$ surface, such as $-\mathrm{COOH},-\mathrm{H}_{2} \mathrm{PO}_{3},-\mathrm{SO}_{3} \mathrm{H}$;

7) thermal and chemical stability, good solubility.
Metal complex dyes that have been widely investigated are based on ruthenium ( $\mathrm{Ru}$ ), iridium (Ir), osmium (Os). These elements are considered as heavy metals; complexes which they create are characterized by a long excited lifetime, high efficiency of DSSC assembly, and high redox properties.

\subsection{Ruthenium ( $R u)$ complex photosensitizers}

Nowadays, the DSCC assemblies that occur the best efficiency are ruthenium-based. They are characterized by high efficiency, excellent chemical stability, and absorption of solar radiation in a wide range. Researchers developed many sensitizers based on ruthenium element. Among them, the most well-known and widely used are N3 ("red" dye), N749 ("black" dye), N719, Z907 complexes. N719 and N3 photosensitizers have almost the same structure; in the molecule of $\mathrm{N} 3$ is $\mathrm{TBA}^{+}$instead of $\mathrm{H}^{+}$at two carboxyl groups. The red and black dyes are often used as indicator ones. Many researchers $[5,11,25]$ are working on N719based dye-sensitized solar cell assemblies, but the highest efficiency equals $11.18 \%$ was obtained by [14]. The most important thing during the optimization of the photosensitizer for solar cells applications is the ratio of electrons injection rates and recombination (reverse and forward electron transport) [13]. High efficiency of the N3 and N719 dye is the result that the injection process is much faster than recombination due to the separation of the donor LUMO orbital and the acceptor HOMO. However, all of Ru-based DSSC obtain similar, excellent efficiency on the level of $10-11 \%$, which is shown in Table 1 . That is caused especially by wide absorption range from visible to near-IR light. In the last years, in the field of dye-sensitized assemblies based on ruthenium, the stagnation can be observed. It is caused by a disadvantageous impact on the environment by their chemical nature. In addition, the synthesis of ruthenium complexes is a sophisticated and expensive procedure, and these complexes have a strong tendency to degrade in the water environment [51].

Table 1. The efficiency of the Ru-based dye-sensitized solar cells

\begin{tabular}{|c|c|c|c|}
\hline Dye & Full name & $\eta[\%]$ & Ref. \\
\hline N3 & $\begin{array}{c}\text { cis-bis(isothiocyanato)bis(2,2'-bipyridyl-4,4'- } \\
\text { dicarboxylato)ruthenium(II) }\end{array}$ & 10.00 & {$[48]$} \\
\hline N719 & $\begin{array}{c}\text { di-tetrabutylammonium cis- } \\
\text { bis(isothiocyanato)bis(2,2'-bipyridyl-4,4'- } \\
\text { dicarboxylato)ruthenium(II) }\end{array}$ & 11.18 & {$[14]$} \\
\hline N749 & $\begin{array}{c}\text { tris(N,N,N-tributyl-1-butanaminium)[[2,2"6',2"- } \\
\text { terpyridine]-4,4',4"-tricarboxylato(3-)- } \\
\text { N1,N1',N1']tris(thiocyanato-N)hydrogen ruthenate }\end{array}$ & 10.40 & {$[33]$} \\
\hline Z907 & $\begin{array}{c}\text { cis-Bis(isothiocyanato)(2,2'-bipyridyl-4,4'- } \\
\text { dicarboxylato)(4,4'-di-nonyl-2' } \\
\text { bipyridyl)ruthenium(II) }\end{array}$ & 11.10 & {$[6]$} \\
\hline
\end{tabular}

Mathew et al. [30] achieved high conversion efficiency for the metal complex-based dyes which was $13 \%$ with the following working parameters: open-circuit voltage $V_{O C}-0.91 \mathrm{~V}$, shortcircuit current density $J_{S C}-18.1 \mathrm{~mA} / \mathrm{cm}^{2}$, fill factor $F F-78 \%$.

\subsection{Natural dyes}

Natural dyes have received intense research interest in recent years. They are considered as promising photosensitizers in dyesensitized solar cells field because of low cost, resource reproducibility, non-toxic environmental impact, and their abundance of prevalence. The biggest advantage of dyes based on natural substances is that they are never threatened with extinction, even with very high usage. Pigments in natural dyes can be easily extracted from flowers, leaves, and fruits of some plants [9]. Each part of the natural plant is characterized by different pigment colour. What is more, obtaining natural dyes and optimization of extraction methods are less sophisticated than in case of ruthenium complexes, and thus the negative impact on the natural environment can be easily reduced [4]. 
Natural sensitizers are characterized by absorption in the range 400-700 nm (visible region range) [23, 31]. Natural dyes present widely spectrum of colours from light yellow to dark brown. These substances are often used for educational purposes in order to evaluate which type of dyes are suitable for sensitization. Among them, the most investigated are chlorophyll, anthocyanin, carotenoids, flavonoids.

Chlorophyll and anthocyanin will be described as a representative dyes of this group of photosensitizers.

\subsubsection{Chlorophyll}

Chlorophyll is one of the most abundant dye. It occurs in almost all plants and is characterized by green colour (it is called "natural green dye"). Chlorophyll can be easily extracted, especially from leaves. This dye can absorb the light from red, blue and violet wavelengths. The strong absorption peaks can be observed at $430 \mathrm{~nm}$ and $660 \mathrm{~nm}$ [40]. The very first research about chlorophyll as a photosensitizer was published in 1972 by Tributsch [44]. The structure of the chlorophyll dye is presented in Fig. 2.

Taya et al. [41] presented the research in which chlorophyll was extracted from anethum graveolens, parsley, arugula, spinach oleracea, and green algae. It was shown that the condition of the basic material matters. Fresh or dried leaves from plants mentioned above affect strongly the adsorption of chlorophyll onto the photoanode surface and consequently the performance. This research group obtained results before and after drying and the best efficiency was obtained for DSSC assembly sensitized by the spinach oleracea with drying process implemented equals $0.29 \%$.

The dye-sensitized solar cells can be also sensitized by chlorophyll extracted from fig leaves. The highest energy conversion efficiency obtained with the fig leaves was reported at [42] and it is equal to $0.64 \%$. Also, a dye extracted from cream leaves resulted in good performance of the DSSC $(0.607 \%)$.

The research group of Kabir et al. [20] reported stability study of natural green dye extracted from spinach leaves (Spinacia oleracea), prepared with methanol. They obtained the dyesensitized chlorophyll-based assemblies with an efficiency of $0.398 \%$. Then the stability test was made which showed the diminishing efficiency to $0.395 \%$ after a period of 192 hours. However, the degradation rate deteriorated with time as well.

Wang et al. [47] have extracted chlorophyll dyes from brown seaweed, $U$. pinnatifida. They examined two different types of chlorophyll and their oxidized forms. For each type of c-type chlorophyll, they obtained very high conversion efficiencies up to $3.40 \%$ and $4.60 \%$ for basic dyes; $2.60 \%$ and $2.50 \%$ for their oxidized forms.

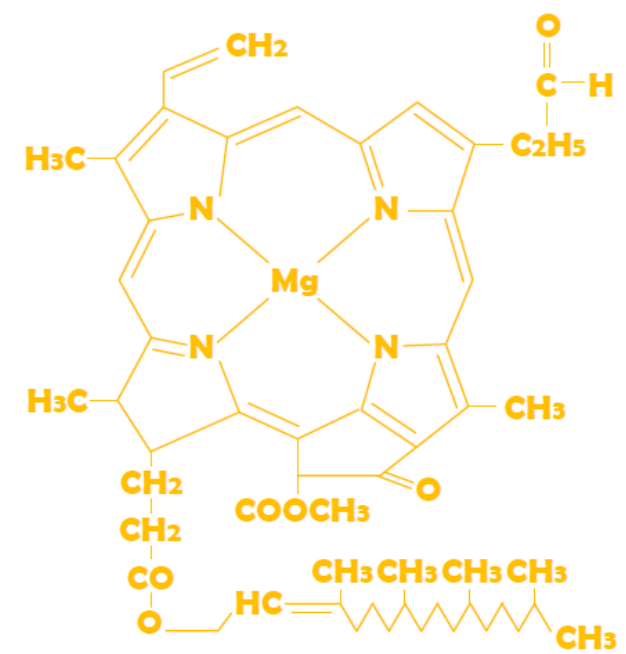

\subsubsection{Anthocyanin}

Anthocyanin is classified as a part of large flavonoids group. The use of anthocyanin in DSCC results in intense red to blue colour. Besides the chlorophyll, it is the most important group of visible plant pigments. Anthocyanins are also well-known due to their excellent antioxidant properties. This natural pigment is characterized by wide absorption in the range of $450-600 \mathrm{~nm}$ due to charge transfer transitions from HOMO to LUMO [16]. Big advantage of this dye is the presence of carbonyl and hydroxyl groups in the molecular structure (Fig. 3) which helps in attaching with $\mathrm{TiO}_{2}$ molecules for good sensitization, and thus good energy conversion efficiency of sensitized assembly. Anthocyanin can be found in a wide group of plants in their leaves, fruits, petals, and roots [39]. Blackberries, grapes, aubergines, mango, blueberries, red onion or red cabbage are the main origin of the anthocyanin dye. The colour of the sensitized $\mathrm{TiO}_{2}$ matters, darker anthocyanin pigment leads to higher efficiency [36]. Darker colour enhances light absorption and thus caused better conversion energy efficiency.

Adel et al. [2] used anthocyanin dyes extracted from three different plants: blackberry, hibiscus, and rose. They achieved the efficiency of $0.76 \%, 0.058 \%, 0.044 \%$ for blackberry, hibiscus, and rose dye, respectively with the use of iodine electrolyte.

The research group of Calogero et al. [8] used blackberries, red Sicilian orange and aubergine which resulted in dye-sensitized solar cells worked with the efficiency of $1.15 \%, 1.01 \%$, and $0.64 \%$ respectively. The obtained DSSC worked with the $J_{s c}, V_{o c}$ and $F F$ parameters which were equal to $7.68 \mathrm{~mA} / \mathrm{cm}^{2}, 348 \mathrm{mV}$ and 0.43 respectively.

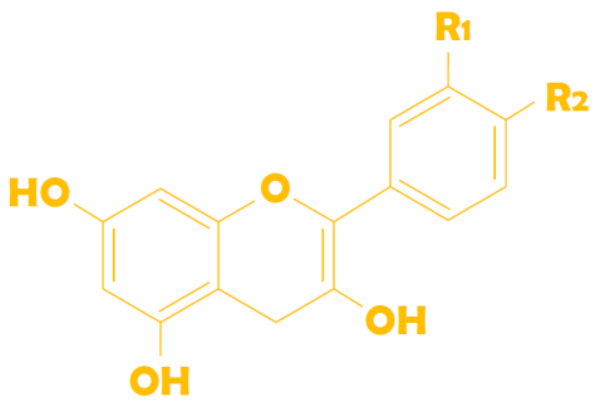

Fig. 3. Basic molecular structure of anthocyanin pigment

However, the anthocyanin dye can be extracted also from pomegranate with high success. In the work of Ghann et al. [15] the efficiency of $2.00 \%$ has reported. They observed a strong absorption peak at $510 \mathrm{~nm}$ which matches with anthocyanins' absorption range. The dye-sanitized assemblies worked with $V_{o c}-$ $390 \mathrm{mV}, J_{s c}-12.20 \mathrm{~mA} / \mathrm{cm}^{2}$ and $\mathrm{FF}$ parameter equal to 0.41 .

It should be mentioned that natural an anthocyanin dyes have synthetic derivatives which show promising properties as efficient sensitizers for dye-sensitized solar cells.

\subsection{Metal-free organic dyes}

Organic dyes used in dye-sensitized solar cells field are characterized by high molar absorption, the wide diversity of molecular structures which enable to model vast variety of dyes, low cost, and flexibility for molecular designing. However, in comparison with metal complexes-based dyes, they obtained lower conversion efficiencies.

The design of organic sensitizers is typically based on the configuration " $\mathrm{D}-\pi-\mathrm{A}$ ", where $\mathrm{D}$ is a hydrophobic electron rich donor, $\pi$-bridge, A - hydrophilic electron-deficient acceptor. The acceptor is also a structure which anchors the titanium dioxide semiconductor layer. The typical structure is shown in Fig. 4. This structure is also known as the 'push-pull' structure or ' $\mathrm{DpA}$ ' [27]. 


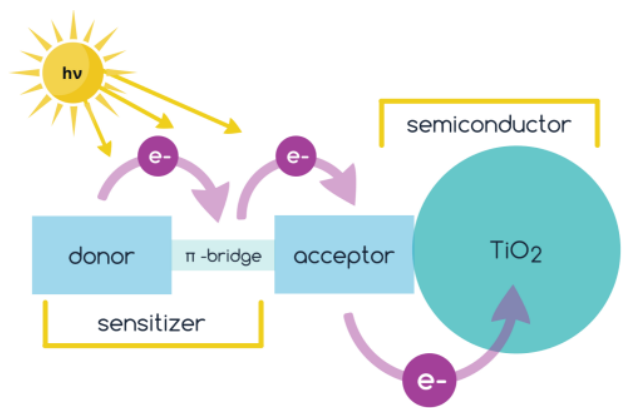

Fig. 4. Scheme of donor- $\pi$-acceptor organic dye structure

The main factor which can limit the efficiency of working DSSC sensitized with organic dyes is the occurrence of dye aggregates formation on the surface of $\mathrm{TiO}_{2}$ nanoparticles which caused suppressing of the excited state of the sensitizer molecules.

It can be distinguished many metal-free organic dyes classes which are the subject of investigation. Among them, alizarin, coumarin, cyanine, triphenylamine, carbazole-based sensitizers which obtained the efficiency up to $5-9 \%$ [37, 52] can be underlined.

Alizarin is one of the metal-free organic dyes which results in red colour in DSSC. This dye is characterized by rapid injection electrons into the semiconductor conduction band with the indirect mechanism. The dye has wide absorption $(400-600 \mathrm{~nm})$ with the strongest peak at $432.5 \mathrm{~nm}$ [22]. The molecular structure of alizarin is shown in Fig. 5.

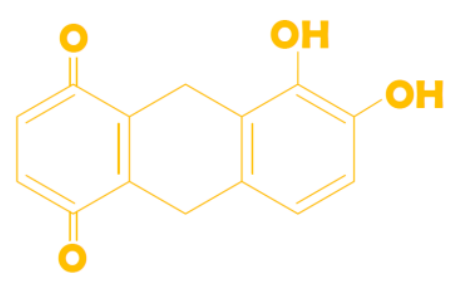

Fig 5. Basic molecular structure of alizarin pigment

In the paper by [35], the working parameters of alizarin-based DSSC with four different redox couple electrolytes e.g. (KI), $\left[\left(\mathrm{CH}_{3}\right)_{4} \mathrm{NI}\right], \quad\left[\left(\mathrm{CH}_{3} \mathrm{CH}_{2}\right)_{4} \mathrm{NI}\right]$ and $\left[\left(\mathrm{CH}_{3} \mathrm{CH}_{2} \mathrm{CH}_{2}\right)_{4} \mathrm{NI}\right]$ were examined. They achieved the dye-sensitized assemblies worked with the efficiency of $0.635 \%, 0.383 \%, 0.78 \%$, and $0.915 \%$.

Whereas, the research group of Manmeeta [29] fabricated two types of assemblies: $\mathrm{TiCl}_{4}$ treated and untreated $\mathrm{TiO}_{2}$ material with the use of oxidized alizarin photosensitizer. In the first group, they obtained $J_{S C}, V_{O C}, F F$ and efficiency parameter equals to $9 \mathrm{~mA} / \mathrm{cm}^{2}, 750 \mathrm{mV}, 0.53$ and $3.57 \%$ respectively. However, the research has shown that $\mathrm{TiCl}_{4}$ treatment significantly improves all working parameters, especially energy conversion efficiency $(5.12 \%)$.

Tsao et al. [45] reported the power conversion efficiency of $10.3 \%$ by use of organic dye (Y123) and cobalt base electrolyte. Nevertheless, a very good effect can be observed by cosensitization with two metal-free organic sensitizers. Kakiage et al. [21] demonstrated sensitized DSSC with ADEKA-1 and a carboxy-anchor organic dye of LEG4 collaboratively which show an excellent record of efficiency, up to $14.30 \%$.

\section{Conclusion}

Dye-sensitized solar cells are a generation of photovoltaic devices which is intense explored and thus developed over the three decades. However, still many components need to be improved in order to enhance working parameters $\left(V_{O C}, I_{S C}, J_{S C}\right.$, $F F$ ) and efficiency of DSSC assemblies. Dyes presented in this review article are only a small part of a broad group of photosensitizers. Molecular structure of dyes can be easily modified which resulted in nearly infinite types of photosensitizers. Nevertheless, there is a strong need for highperformance dyes which increase light adsorption by the semiconductor material. The very high efficiencies are obtained by ruthenium-based dye-sensitized solar cells by now (up to $11 \%$ ), however, they should be replaced with metal-free dyes with the nontoxic influence of environment. Natural dyes extracted from plants seem to be a promising alternative as well as organic dyes with efficiencies reaching $9 \%$. However, it should be clarified that not only the photosensitizer but also other components and their mutual adjustment is of high importance. Wherefore, a new approach to co-sensitization results in the value of efficiencies which can be compared with those for $\mathrm{Ru}$ sensitizers. The comprehensive discussion allows to suggest that utilization of natural and metal-free dyes in DSSC result in high performances in the foreseeable future.

\section{References}

[1] Adedokun O., Titilope K., Awodugba A.O.: Review on natural dye-sensitized solar cells review on natural dye-sensitized solar cells (DSSCs). International Journal of Engineering Technologies 2/2016, 34-41, [DOI: 10.19072/ijet.96456].

[2] Adel R., Abdallah T., Moustafa Y.M., Al-sabagh A.M., Talaat, H.: Effect of polymer electrolyte on the performance of natural dye sensitized solar cells. Superlattices and Microstructures 86/2015, 62-67, [DOI: 10.1016/j.spmi.2015.07.024].

[3] Ahmad S., Guillén E., Kavan L., Grätzel M., Nazeeruddin M.K.: Metal free sensitizer and catalyst for dye sensitized solar cells. Energy \& Environmental Science 6/2013, 3439-3466, [DOI: 10.1039/C3EE41888J].

[4] Ayalew W.A., Ayele D.W.: Dye-sensitized solar cells using natural dye as lightharvesting materials extracted from Acanthus sennii chiovenda flower and Euphorbia cotinifolia leaf. Journal of Science: Advanced Materials and Devices 1/2016, 488-494, [DOI: 10.1016/j.jsamd.2016.10.003].

[5] Bakr N., Ali A., Jassim S., Hassoon K.: Effect of N719 Dye Concentration on the Conversion Efficiency of Dye Sensitized Solar Cells. ZANCO Journal of Pure and Applied Sciences 29/2017, 274-280 [DOI: 10.21271/ZJPAS.29.s4.31].

[6] Bessho T., Constable E.C., Graetzel M., Redondo A.H., Housecroft C.E., Kylberg W., Nazeeruddin M.K., Neuburgerb M., Schaffner S.: An element of surprise - efficient copper-functionalized dye-sensitized solar cells. Chemical Communications 32/2008, 3717-3719, [ DOI: 10.1039/B808491B].

[7] Blaschke T., Biberacher M., Gadocha S., Schardinger I.: 'Energy landscapes' Meeting energy demands and human aspirations. Biomass and Bioenergy 55/ 2013, 3-16, [DOI: 10.1016/j.biombioe.2012.11.022].

[8] Calogero G., Yum J.-H., Sinopoli A., Di Marco G., Gratzel M., Nazeeruddin M. K.: Anthocyanins and betalains as light-harvesting pigments for dye-sensitized solar cells. Solar Energy 86/2012, 1563-1575, [DOI: 10.1016/j.solener.2012.02.018].

[9] Chang H., Lo Y.-J.: Pomegranate leaves and mulberry fruit as natural sensitizers for dye-sensitized solar cells. Solar Energy 84/2010, 1833-1837, [DOI: 10.1016/j.solener.2010.07.009].

[10] Chiba Y., Islam A., Watanabe Y., Komiya R., Koide N., Han, L.: Dye-sensitized solar cells with conversion efficiency of $11.1 \%$. Japanese Journal of Applied Physics 45/2006, 24-28, [DOI: 10.1143/JJAP.45.L638]

[11] De Angelis F., Fantacci S., Mosconi E., Nazeeruddin M.K., Grätzel M. Absorption Spectra and Excited State Energy Levels of the N719 Dye on TiO2 in Dye-Sensitized Solar Cell Models. The Journal of Physical Chemistry C 115/211, 8825-8831, [DOI: 10.1021/jp111949a].

[12] Dobrzański L.A., Szindler M.M., Szindler M., Dudek A., Krawiec K.: The influence of natural and synthetic dyes on the absorbance of nanocrystalline $\mathrm{TiO} 2$ used in dye sensitized solar cells. Journal of Achievements in Materials and Manufacturing Engineering 69/2015, 53-58.

[13] Durrant J.R., Haque S.A., Palomares E.: Towards Optimisation of Electron Transfer Processes in Dye Sensitised Solar Cells. Coordination Chemistry Reviews 248/2004, 1247-1257, [DOI: 10.1016/j.ccr.2004.03.014].

[14] Funaki T., Yanagida M., Onozawa-Komatsuzaki N., Kawanishi Y., Kasuga K.,, Sugihara H.: A 2-quinolinecarboxylate-substituted ruthenium(II) complex as a new type of sensitizer for dye-sensitized solar cells. Inorganica Chimica Acta 362/2009, 2519-2522, [DOI: 10.1016/j.ica.2008.10.019].

[15] Ghann W., Kang H., Sheikh T., Yadav S., Chavez-Gil T., Nesbitt F., Uddin J. Fabrication, Optimization and Characterization of Natural Dye Sensitized Solar Cell. Scientific Reports 7/2017, 1-12, [DOI: 10.1038/srep41470].

[16] Hemmatzadeh R., Jamali A.: Enhancing the optical absorption of anthocyanins for dye-sensitized solar cells. Journal of Renewable and Sustainable Energy 7/2015, [DOI: 10.1063/1.4907599].

[17] Iqbal M.Z., Ali S.R., Khan S.: Progress in dye sensitized solar cell by incorporating natural photosensitizers. Solar Energy 181/2019, 490-509, [DOI: 10.1016/j.solener.2019.02.023].

[18] Jackson P., Wuerz R., Hariskos D., Lotter E., Witte W., Powalla M.: Effects of heavy alkali elements in $\mathrm{Cu}(\mathrm{In}, \mathrm{Ga}) \mathrm{Se} 2$ solar cells with efficiencies up to $22.6 \%$. Physica Status Solidi 10/2016, 583-586, [DOI: 10.1002/pssr.201600199].

[19] Jonathan E., Onimisi M.Y., Eli D.: Natural pigments as sensitizers for dye sensitized solar cells. Advances in Materials 5/2016, 31-34, [DOI: 10.11648/j.am.20160505.11].

[20] Kabir F., Sakib S.N., Matin N.: Stability study of natural green dye based DSSC Optik 181/2019, 458-464, [DOI: 10.1016/j.ijleo.2018.12.077].

[21] Kakiage K., Aoyama Y., Yano T., Oya K., Fujisawa J.-I., Hanaya M.: Highlyefficient dye-sensitized solar cells with collaborative sensitization by silyl- 
anchor and carboxy-anchor dyes, Chemical Communications 51/2015, 15894 15897, [DOI: $10.1039 / \mathrm{c} 5 \mathrm{cc} 06759 \mathrm{f}]$.

[22] Krawczak E., Zdyb A.: The influence of the dye adsorption time on the DSSC performance. E3S Web of Conferences 100/2019, [DOI:
[ 10.1051/e3sconf/201910000040].

[23] Kumar, R., Sharma, A.K., Parmar, V.S., Watterson, A.C., Chittibabu, K.G., Kumar, J., Samuelson, L.A.: Flexible, dye-sensitized nanocrystalline solar cells employing biocatalytically synthesized polymeric electrolytes. Chemistry of Materials 16/2004, 4841-4846, [DOI: 10.1021/cm0496568].

[24] Lee C.-P., Lin R. Y.-Y., Lin L.-Y., Li C.-T., Chu T.-C., Sun S.-S, Lin J. T., Ho K.-C.: Recent progress in organic sensitizers for dye-sensitized solar cells. RSC Advances 5/2015, 23810-23825, [DOI: 10.1039/C4RA16493H].

[25] Lee K. E., Gomez M. A., Elouatik S., Demopoulos G. P.: Further Understanding of the Adsorption Mechanism of N719 Sensitizer on Anatase TiO2 Films for DSSC Applications Using Vibrational Spectroscopy and Confocal Raman Imaging. Langmuir 26/2010, 9575-9583, [DOI: 10.1021/la100137u].

[26] Li W., Lv F., Shu T., Tan X., Jiang L., Xiao T., Xiang P.: Improving the performance of FTO conducting glass by $\mathrm{SiO} 2$ and $\mathrm{ZnO}$ anti-reflection films for dye-sensitized solar cells. Materials Letters 243/2019, 108-111, [DOI: 10.1016/j.matlet.2019.01.158].

[27] Mahmood A.: Triphenylamine based dyes for dye sensitized solar cells: a review. Solar Energy 123/2016, 127-144, [DOI:
? 10.1016/j.solener.2015.11.015].

[28] Mallick A., Basak D.: Revisiting the electrical and optical transmission properties of co-doped $\mathrm{ZnO}$ thin films as n-type TCOs. Progress in Materials Science 96/2018, 86-110, [DOI: 10.1016/j.pmatsci.2018.03.004].

[29] Manmeeta, Dhiraj S., Sharma G.D., Roy M.S: Improved performance of oxidized Alizarin based Quasi solid state Dye Sensitized solar cell by Surface Treatment. Research Journal of Chemical Sciences 2/2012, 61-71.

[30] Mathew S., Yella A., Gao P., Humphry-Baker R., Curchod B.F., Ashari-Astani N., Tavernelli I., Rothlisberger U., Nazeeruddin M.K., Gratzel M.: Dyesensitizedsolar cells with $13 \%$ efficiency achieved through the molecular engineering of porphyrin sensitizers. Nature Chemistry 6/2014, 242-247, [DOI: 10.1038/nchem.1861].

[31] Mehmood, U., Rahman, S.-U., Harrabi, K., Hussein, I.A., Reddy, B.: Recent advances in dye sensitized solar cells. Advances in Materials Science and Engineering 2014, 1-12, [DOI: 10.1155/2014/974782].

[32] O'Regan B., Grätzel M.: A low-cost, high-efficiency solar cell based on dyesensitized colloidal $\mathrm{TiO}_{2}$ films. Nature 353/1991, 737-740, [DOI: $10.1038 / 353737 \mathrm{a} 0]$.

[33] Polo A.S., Itokazu M.K., Iha N.Y.M.: Metal complex sensitizers in dye sensitized solar cells. Coordination Chemistry Reviews 248/2004, 1343-1361, [DOI: 10.1016/j.ccr.2004.04.013].

[34] Roslan N., Ya'acob M.E., Radzi M.A.M., Hashimoto Y., Jamaludin D., Chen G.: Dye Sensitized SolarCell (DSSC) greenhouse shading: New insights for solar radiation manipulation. Renewable and Sustainable Energy Reviews 92/2018, 171-186, [DOI: 10.1016/j.rser.2018.04.095].

[35] Saini R. K., Kadyan P. S., Singh J., Bhagwan S., Singh D.: Fabrication and Photovoltaic Characteristics of Alizarin Dye Based DSSCs. Der Pharma Chemica 11/ 2019, 43-48 [ISSN 0975-413X].

[36] Sawhney N., Raghav A., Satapathi S.: Utilization of Naturally Occurring Dyes as Sensitizers in Dye Sensitized Solar Cells. IEEE Journal of Photovoltaics 7/2016, 539-544, [DOI: 10.1109/JPHOTOV.2016.2639343]

[37] Shelke R.S., Thombre S.B., Patrikar S.R.: Status and perspectives of dyes used in dye sensitized solar cells. International Journal of Renewable Energy Research 3/2013, 54-61.

[38] Shikoh A. S., Ahmad Z., Touati F., Shakoor R.A., Al-Muhtaseb S. A.: Optimization of ITO glass/TiO2 based DSSC photo-anodes through electrophoretic deposition and sintering techniques. Ceramics International 43/2017, 10540-10545, [DOI: 10.1016/j.ceramint.2017.05.113].

[39] Singh A.M.B.G., Durai A., Murugeasan S.: Evaluation of Colour and Stability of Anthocyanin in Red Tamarind (Tamarindus indica L). International Journal of Advanced Life Sciences 5/2012, 137-144.

[40] Syafinar R., Gomesh N., Irwanto M., Fareq M., Irwan Y.M.: Chlorophyll pigments as nature based dye for dye-sensitized solar cell (DSSC). Energy Procedia 79/2015, 896-902, [DOI: 10.1016/j.egypro.2015.11.584].
[41] Taya S.A., El-Agez T.M., El-Ghamri H.S., Abdel-Latif M.S.: Dye-sensitized solar cells using fresh and dried natural dyes. International Journal of Materials Science and Applications 2/2013, 37-42, [DOI: 10.11648/j.ijmsa.20130202.11].

[42] Taya S.A., El-Agez T.M., Elferi K.S.: Dye-sensitized solar cells based on dyes extracted from dried plant leaves. Turkish Journal of Physics 39/2015, 24-30, [DOI: 10.3906/fiz-1312-12].

[43] Tennakone K., Bandara J.: Photocatalytic activity of dye-sensitized tin(IV) oxide nanocrystalline particles attached to zinc oxide particles: long distance electron transfer via ballistic transport of electrons across nanocrystallites. Applied Catalysis A General 208/2001, 335-341, [DOI: 10.1016/S0926860X(00)00738-9].

[44] Tributsch H.: Reaction of excited chlorophyll molecules at electrodes and in photosynthesis. Journal of Photo-chemistry and Photobiology 16/1972, 261269, [DOI: 10.1111/j.1751-1097.1972.tb06297.x]

[45] Tsao H.N., Burschka J., Yi C., Kessler F., Nazeeruddin M.K., Grätzel M. Influence of the interfacial charge-transfer resistance at the counter electrode in dye-sensitized solar cells employing cobalt redox shuttles. Energy \& Environmental Science 4/2011, 4921-4924, [DOI: 10.1039/C1EE02389F].

[46] Türkay B.E., Telli A.Y.: Economic Analysis of Stand Alone and Grid Connected Hybrid Energy Systems. Renewable Energy 36/2011, 1931-1943, [DOI: 10.12691/ajme-4-5-3].

[47] Wang X.-F., Zhan C.-H., Maoka T., Wada Y., Koyama Y.: Fabrication of dyesensitized solar cells using chlorophylls $\mathrm{c} 1$ and $\mathrm{c} 2$ and their oxidized forms $\mathrm{c} 1$ and c2' from Undaria pinnatifida (Wakame). Chemical Physics Letters 447/2007, 79-85, [DOI: 10.1016/j.cplett.2007.08.097].

[48] Wei D.: Dye Sensitized Solar Cells. International Journal of Molecular Sciences 11/2010, 1103-1113, [DOI: 10.3390/ijms11031103]

[49] Yella A., Lee H.-W., Tsao H.N., Yi C., Chandiran A K., Nazeeruddin Md.K., Diau E.W.-G., Yeh C.-Y., Zakeeruddin S.M., Grätzel M.: Porphyrin-Sensitized Solar Cells with Cobalt (II/III)-Based Redox Electrolyte Exceed 12 Percent Efficiency. Science 334/2011, 629-634, [DOI: 10.1126/science.1209688].

[50] Yoshikawa K., Kawasaki H., Yoshida W., Irie T., Konishi K., Nakano K., Uto T., Adachi D., Kanematsu M., Uzu H., Yamamoto K.: Silicon heterojunction solar cell with interdigitated back contacts for a photoconversion efficiency over 26\%. Nature Energy 2/2017, 1-8, [DOI: 10.1038/nenergy.2017.32].

[51] Zhang D., Lanier S.M., Downing J.A., Avent J.L., Lum J., McHale J.L.: Betalain pigments for dyesensitized solar cells. Journal of Photochemistry and Photobiology A: Chemistry 195/2008, 72-80, [DOI:
[ 10.1016/j.jphotochem.2007.07.038].

[52] Zhang S., Yang X., Numata Y., Han L.: Highly efficient dye-sensitized solar cells: progress and future challenges. Energy \& Environmental Science 6/2013,1443-1464, [DOI: 10.1039/C3EE24453A].

[53] Eurepean Commisssion Statement, http://europa.eu/rapid/pressrelease_STATEMENT-18-4155_en.htm [01.08.2019].

[54] International Energy Agency, Executive Summary, 2018, IEA Publications, https://webstore.iea.org/download/summary/190?fileName=English-WEO2018-ES.pdf [01.08.2019].

\section{M.Sc Eng. Ewelina Krawczak}

e-mail:e.krawczak@pollub.p

Ph.D. student and assistant at Faculty of Environmental Engineering, Lublin University of Technology. Research area concerns renewable energy sources, especially transparent conductive oxides, optimization of magnetron sputtering deposition process, and performance parameters of dye-sensitized solar cells.

ORCID ID: 0000-0001-9951-3348

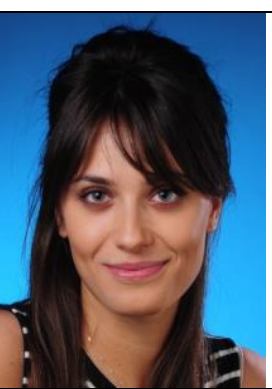

otrzymano/received: 30.05 .2019 